УДК 614.253.52:616.915

DOI 10.11603/2411-1597.2019.1.9975

\title{
РОЛЬ МЕДИЧНОЇ СЕСТРИ ПЕРВИННОЇ ЛАНКИ МЕДИЧНОЇ ДОПОМОГИ ПРИ ВИЯВЛЕННІ НА ДІЛЬНИЦІ ХВОРИХ НА КІР
}

\author{
Ю. О. Данилевич, С. О. Ястремська, Л. П. Мазур \\ ДВНЗ «Тернопільський державний медичний університет \\ імені І. Я. Горбачевського МОЗ Украӥни»
}

У статті розглянуто і висвітлено проблеми захворюваності на кір в Україні та роль медичної сестри первинної ланки медичної допомоги педіатричного профілю.

\section{THE ROLE OF THE FIRST LINE NURSE IN THE CONDITION OF CASE DETECTION OF MEASLES}

\author{
Yu. O. Danylevych, S. O. Yastremska, L. P. Mazur \\ I. Horbachevsky Ternopil State Medical University
}

The article describes the problems of incidence rate of measles in Ukraine as well as the role of the first line pediatric nurse in those conditions.

Вступ. У 2017-2018 рр. Україну сколихнув спалах кору - одного з найбільш заразних інфекційних захворювань, відомих у світі. Індекс контагіозності становить 96-98 \%. За інформацією Центру громадського здоров'я Міністерства охорони здоров'я України, з початку 2018 р. на кір захворіли 36455 людей - 14111 дорослих і 22344 дитини. За прогнозами медиків, до кінця року кількість хворих на кір може перевищити найвищий показник захворюваності, що був зафіксований в Україні, починаючи з 1991 р. Відповідно до статистики МОЗ України, з 2016 р. менше половини дітей отримали щеплення від кору за графіком, тому настороженість щодо підвищення захворюваності на кір не зникає і в 2019 р. [1]. Захворюваність на кір продовжує зростати. За останніми даними Центру громадського здоров'я МОЗ України, за січень 2019 р. на кір в Україні захворіли 15 тис. людей, з них більше половини - діти. Спалахи кору мають циклічний характер і відбуваються кожні 5-6 років. Головною причиною $є$ низький рівень імунізації, тобто охоплення щепленнями, зокрема дитячого населення.

За даними Всесвітньої організації охорони здоров'я, імунізація проти кору дозволила у 2000-2013 рр. знизити смертність від цього захворювання на $75 \%$. Тим не менше, в 2013 р. від кору померли близько
145 тис. чоловік. Дослідники підрахували, що після впровадження вакцини проти кору в розвинених країнах дитяча смертність від інфекційних захворювань знизилася на $50 \%$.

Найчастіше хворіють на кір діти віком 5-9 років, які не отримали другу дозу КПК взагалі або отримали їі не за графіком, через це у них не сформувався імунітет до хвороби.

Загальновідомо, що на кір хворіють тільки люди, відповідно, і зараження відбувається тільки від людини до людини. Вірус кору передається повітрянокраплинним шляхом при тісному контакті з хворим від моменту появи перших симптомів хвороби до 5 дня від початку висипки. Варто пам'ятати, що кір не передається через побутові предмети та третіх осіб, які контактували з інфікованими [5].

Основна частина. Вирішальну роль у попередженні розповсюдження корової інфекції відіграє своєчасно та правильно проведена робота працівниками первинної ланки медичної допомоги і, зокрема медсестрами, високий професіоналізм яких $\in$ найважливішим фактором у цій ситуації.

По-перше, це організація вакцинації дитячого населення згідно з затвердженим Календарем щеплень (рис. 1) [2]. 


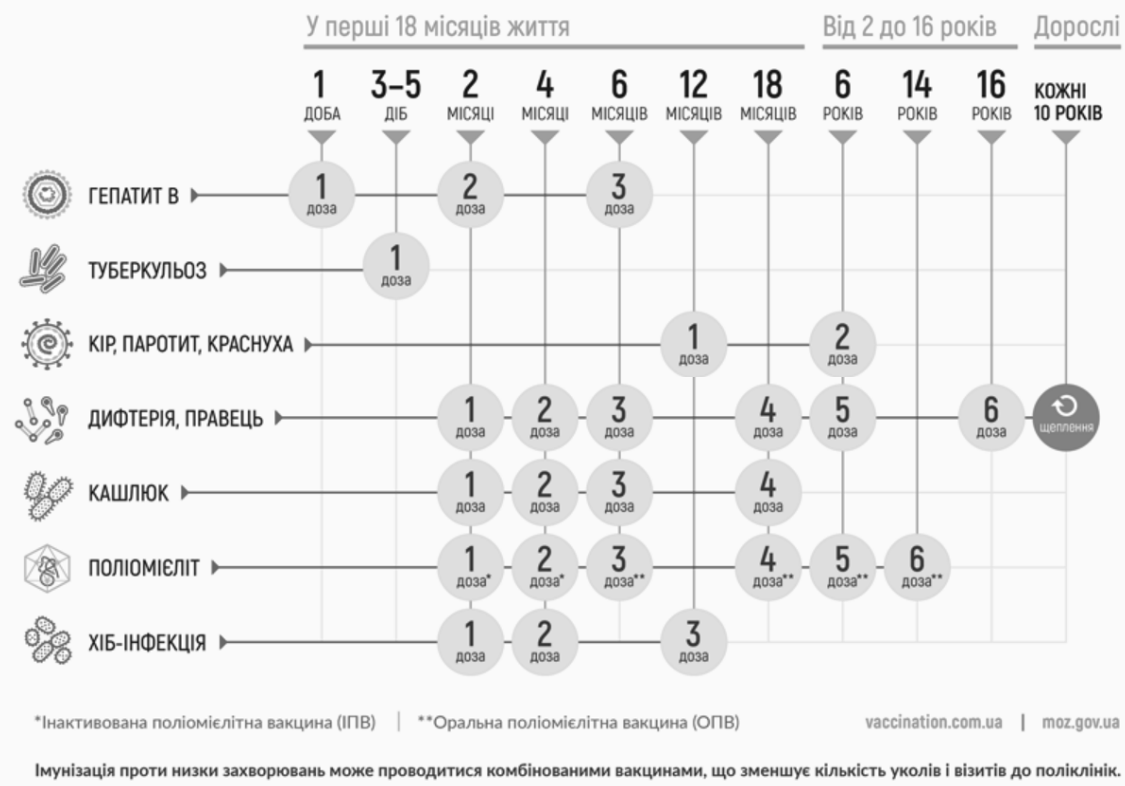

Рис. 1. Календар профілактичних щеплень.

За інформацією Центру громадського здоров'я Міністерства охорони здоров'я України по Тернопільській області, станом на 01.01.19 р. охоплення щепленням становить: КПК-1 (1 рік) - 94,5 \%, КПК-1 (2 роки і старше) - 97,2 \%, КПК-2 (6 років) - 93,6 \%, КПК-2 (7 років і старше) - 90,4 \%. Проте, варто пам'ятати, що зупинити поширення інфекції може лише вакцинація населення на рівні 98 \% [2], а в деяких областях України, зокрема Закарпатській та Харківській, рівень охоплення дитячого населення щепленнями КПК-1 (1 рік) 84,8 і 80,0 \% відповідно.

По-друге, своєчасне виявлення та облік хворих на кір із визначенням осіб, із якими був контакт, і проведення профілактичних й протиепідемічних заходів у сім'ї та навчально-виховних закладах, які відвідувала дитина, з метою виявлення і відсторонення від навчання осіб з ознаками інфекційних захворювань. У разі виявлення хворого на кір в організованих колективах розробляють план протиепідемічних заходів; забезпечують максимально можливу ізоляцію групи (класу) від іншого колективу на 21 день, забороняють приймати нещеплених осіб і осіб без довідки про щеплення або про перенесене захворювання на кір на термін карантину; встановлюють щоденний медичний нагляд за особами, які перебували в контакті з захворілим упродовж 21 дня, посилюють дезінфекційні заходи. Отже, важливо роз'яснити необхідність щоденного проведення термометрії всім контактним особам та огляд шкіри на наявність висипання [5].

Медсестра проводить перевірку карт щеплень членів родини та всіх контактних осіб. Усім людям, які були у контакті та не мають достовірної інформації про вакцинацію або перенесене в минулому захворювання, пропонують визначити титри Ig G проти вірусу кору в крові. Якщо антитіла не виявлені - це свідчить про відсутність імунітету до хвороби і таких осіб потрібно вакцинувати.

По-третє, медсестра інформує батьків або відповідальних за дитину осіб про важливі симптоми захворювання та необхідність дотримання суворого ліжкового режиму. Основними симптомами кору $\epsilon$ сильний головний біль, слабкість, підвищення температури тіла до 40 градусів, втрата апетиту, нежить, сухий і сильний кашель, почервоніння і набряк горла, сірувато-білуваті дрібні висипання (розміром - з макове зернятко) у роті, на слизовій оболонці навпроти кутніх зубів, збільшення лімфовузлів, запалення слизової оболонки очей, висипання на тілі у вигляді дрібних рожево-червоних цяток і пухирців, які поступово перетворюються на більші плями [3]. Важливим симптомом також $\epsilon$ етапність висипань - спершу висипання з'являється на шкірі голови, на обличчі та за вухами, а пізніше розповсюджується на тіло, руки та ноги [5].

Якщо захворювання у дитини перебігає без ускладнень, такі пацієнти можуть лікуватися вдома під наглядом лікаря. Медична сестра зобов'язана точно і кваліфіковано виконувати вказівки лікаря [4]. У той самий час медична сестра має правильно будувати довірливі взаємостосунки з батьками та близькими хворої дитини. Доброзичливість, делікатність, тактовність, вміння переконувати та витримка $\epsilon$ тими про- 
фесійними рисами характеру медсестри, які допомагають у роботі й забезпечують позитивний результат.

По-четверте, важливою частиною роз'яснювальної роботи в сім'ї хворої на кір дитини $\epsilon$ інформування батьків або відповідальних за дитину осіб про можливість розвитку ускладнень, оскільки кір послаблює імунітет і знижує здатність організму боротися 3 іншими хворобами, тому організм стає чутливим до будь-якої бактеріальної інфекції. Ускладнення можуть спричинити захворювання дихальних шляхів: пневмонію, бронхіт, у дітей часто виникає запалення середнього вуха. Кір впливає і на нервову систему та в деяких випадках може призвести до енцефаліту (запалення головного мозку) [3]. Найчастіше ускладнення спостерігають у дітей до 5 років або в дорослих старше 20 років.

Ознаками ускладнень кору $\epsilon$ те, що на 4-5 день після появи перших симптомів кору температура хворого знову зростає до $39-40{ }^{\circ} \mathrm{C}$. До того ж, у хворого посилюється нежить, набрякають повіки та обличчя. Дітей з кором також турбує головний біль, від якого вони інколи навіть непритомніють. До симптомів може додатися ще й пронос.

Кір має таку особливість: навіть після повного зникнення проявів хвороби відновлювальний процес в організмі не закінчується. Дитина, яка перехворіла, досить довго може відчувати швидку втому, млявість, подекуди дратівливість. Кілька тижнів або навіть місяців після перенесеного кору ослаблений загальний імунітет. Ось чому в період одужання важливо оберігати дитину від інфекцій.

Важливо також відзначити, що вірус кору нестійкий до впливу зовнішнього середовища і гине під час кип'ятіння чи дезінфекції. За кімнатної температури

\section{СПИСОК ЛІТЕРАТУРИ}

1. Центр громадського здоров'я МОЗ України [Електронний ресурс]. - Режим доступу : http://moz.gov.ua/article/ news/zahvorjuvanist-na-kir-prodovzhue-zrostati-zupinitiposhirennja-infekcii-mozhe-vakcinacija-na-rivni-98.

2. Про внесення змін до Календаря профілактичних щеплень в Україні : наказ МОЗ України від 18.05.2018 р. № 947.

3. Інфекційні хвороби у дітей : національний підручник / Л. І. Чернишова, А. П. Волоха, А. В. Бондаренко, в приміщенні збудник залишається активним упродовж двох днів. Натомість оптимальною для вірусу $\epsilon$ температура нижче від 15 градусів: тоді вірус довго зберігається. Все це підвищує значення проведення санітарно-профілактичних заходів у приміщеннях, де розміщуються колективи, на які накладений карантин.

Висновки. Охоплення щепленням населення на рівні 95-98 \%, своєчасне виявлення хворих на кір дітей, заходи із ізоляції контактних осіб, належне лікування та догляд за хворими мають велике значення у зменшенні рівня захворюваності, зокрема і смертності внаслідок його ускладнень, і важлива роль у цьому належить медсестрі.

Медсестринство - одна з ланок медичної допомоги, яка найбільше наближена до населення, особливо сільської місцевості, і найдоступніша щодо надання йому медичної допомоги, ось чому роль медичної сестри педіатричної ланки первинної допомоги населенню така важлива. Медсестра має володіти професійними знаннями, комунікативними навичками високого рівня в поясненні, консультуванні та наданні медичної допомоги пацієнтам. Медичній сестрі належить головна роль в створенні сприятливої психологічної обстановки у спілкуванні не тільки з пацієнтами, а і з його родиною, що сприяє досягненню кращого результату в лікуванні пацієнта.

Здоров'я дітей - найцінніше надбання цивілізованого суспільства і запорука успішного розвитку держави у майбутньому. Систематична роз'яснювальна робота та поінформованість населення з питань профілактики кору та настороженість, знання та усвідомлення переваг своєчасної імунопрофілактики відіграє провідну роль у здоров'ї громадян.

Ф. І. Лапій ; за ред. Л. І. Чернишової. - К. : ВСВ «Медицина», 2016. - 1024 c.

4. Медсестринство в педіатрії / М. І. Шегедин, С. Д. Орібко, Г. І. Киричук та ін. - Вінниця : Нова книга, 2009. - 312 с.

5. Шегедин М. І. Медсестринство при інфекційних хворобах / М. І. Шегедин, В. В. Кравців, С. В. Барчук. Дрогобич: Відродження, 2005. - 63 с.

Отримано 18.01.19 